\title{
Spatial patterns of seasonal crop production suggest coordination within and across dryland agricultural systems of Hawai $i$ Island
}

\author{
Aurora K. Kagawa-Viviani $^{1}$, Noa Kekuewa Lincoln ${ }^{2}$, Seth Quintus ${ }^{3}$, Matthew P. Lucas $^{4}$ and Thomas W. Giambelluca $^{1}$
}

\begin{abstract}
Hawaiian dryland agriculture is believed to have played an important role in the rise of archaic states and consolidation of political power. At the same time, the sensitivity of agricultural production in dryland field systems to temporal variability in climate would have had implications for economic and political relationships, both competitive and cooperative. In this study, we explore whether and how annual cycles of climate might have constrained seasonal cultivation and crop production in three rain-fed field systems on the Island of Hawai $i$. We utilized a recently developed monthly gridded climate dataset for the Hawaiian Islands to compare the Kohala, Kona, and $\mathrm{Ka}$ ' $\mathrm{u}$ field systems in terms of mean annual climate and seasonality. We found that despite superficial similarities in elevation and annual rainfall, the field systems differ in climatic variables associated with evaporative water loss and in the timing of the rainy season. Aridity, a ratio of evaporative demand to rainfall, is strongly seasonal for Kohala and Ka'u relative to Kona. When we imposed temperature and moisture criteria to visualize seasonal cultivation envelopes defined for sweet potato (Ipomea batatas), we found strong spatial patterns associated with the onset and length of the growing season, and these suggest seasonal complementarity in crop production within and between field systems. This complementarity indicates coordination both within and between field systems through consolidation, coercion, or increased cooperation could have alleviated periodic food stress and contributed to more stable political hierarchies, which may explain similarities in their respective chronologies of development. We suggest that our approach for characterizing seasonal constraints to dryland cultivation provides a useful tool for advancing continued restoration and research in these and other rain-fed dryland systems across Hawai' $i$ and the tropics.
\end{abstract}

Key Words: aridity; Hawai i; human-environment interaction; rain-fed agriculture; seasonality; sweet potato

\section{INTRODUCTION}

Hawaiian traditional agriculture is often categorized into wetland (flooded, irrigated) and dryland (rain-fed) systems of production. Because opportunities for intensification of these two systems were not evenly distributed across the archipelago (Ladefoged et al. 2009), it has been proposed that strong differences in yields, labor requirements, and stability of these two dominant agricultural modes drove the emergence of different political economic structures. Wetland agricultural systems provided high and consistent crop yields, supporting relatively stable economies and political systems (Kirch 1994). In contrast, production in dryland systems was more variable given their dependence on seasonal or intermittent rainfall (Malo 1951, Kamakau 1976, Lee et al. 2006, DiNapoli and Morrison 2017). Despite this, dryland agriculture dominated on the younger islands of Hawai' $i$ and Maui; Ladefoged et al. (2009) estimate that on Hawai'i Island, $97 \%$ of cultivated land was rain-fed.

During the 18th and 19th century in Hawai'i, in the decades immediately prior to and after European arrival, polities from the leeward regions of Hawai'i Island and Maui expanded to unify individual islands and eventually the archipelago. That these predatory polities developed out of the geologically young rainfed regions rather than the more productive irrigated valleys of $\mathrm{O}^{\prime}$ ahu or Kaua'i has been recognized for decades and has been the subject of intensive archaeological inquiry (e.g., Rosendahl 1972, Schilt 1984, Ladefoged et al. 1996, Allen 2001, Ladefoged et al. 2003). Several researchers focused on the increased volatility inherent in cultivated rain-fed systems as opposed to irrigated systems suggest that variation in those systems' annual yield may have led to aggression during times of below-average harvest (Kirch 2010, Hommon 2013). Others have argued that evidence of bad years is lacking and that the field systems' large scale could have been geared toward accumulating wealth assets, e.g., pigs, to support political ambition (Dye 2014), although yield variability could still influence aggression to acquire more wealth assets. In any case, most researchers agree, and modelling suggests, that production variation between the wet and the dry areas of islands and within individual field systems was a key component of increased coordination, whether through coercion or cooperation, apparent after AD 1600 in the archipelago (Allen 2004, Ladefoged and Graves 2008, Ladefoged et al. 2008, DiNapoli and Morrison 2017).

While effects of year-to-year variability in rainfall and yields have been studied, the role of intra-annual variability has been largely ignored. The objective of this study was thus to consider how intra- and interpolity coordination might have been influenced by seasonal water limitation and resulting agricultural production variability on these shorter time scales. We believe this is particularly relevant in the case of tropical root crops with relatively poor postharvest storage because coordination would result in enhanced resource availability to support subsistence and surplus goals. Furthermore, we were interested in how such seasonality is manifested across different rain-fed field systems given Hawai'i's famed environmental heterogeneity. To address our objectives, we focused our attention on three rain-fed field systems on Hawai i Island in the districts of Kohala, Kona, and Ka ${ }^{t} \bar{u}$, asking a series of questions: (1) How do these three field systems compare in terms of mean climate? (2) How are they

${ }^{1}$ Department of Geography and Environment, University of Hawai i i at Mānoa, ${ }^{2}$ Tropical Plant and Soil Sciences Department, University of Hawai i at Mānoa, ${ }^{3}$ Department of Anthropology, University of Hawai i at Mānoa, ${ }^{4}$ Natural Resources and Environmental Management Department, University of Hawaíi at Mānoa 
similar or different in mean annual cycles (seasonality) of climatic variables most relevant to plant growth? (3) How does such climatic seasonality superimposed on steep climatic gradients determine spatial patterns of seasonal cultivation? We discuss implications of observed patterning of production for inter- and intra-polity interaction and integration. Finally, we assess how similar types of agricultural infrastructure in the three field systems likely addressed each system's unique climatic setting.

Constraints to production in dryland systems

Our understanding of Hawaiian dryland field systems' agricultural production potential has been shaped largely by research in leeward Kohala, where the field system is delimited by relatively static biogeochemical characteristics (Vitousek et al. 2004, 2014). Precipitation and substrate age interact to create fertile soil "domains" bounded by thresholds at the upper (wetter) limits across which soil properties such as $\mathrm{P}$, soil $\mathrm{pH}$, exchangeable calcium, and base saturation decrease rapidly with little climate forcing (Vitousek and Chadwick 2013, Vitousek et al. 2014). In the Kona field system, however, agricultural intensification extends well beyond the soil domain and fertility indicators and may represent a different pathway to nutrient limitation (Lincoln et al. 2014). Over time, variation in annual rainfall constrains crop production (Lee et al. 2006, Ladefoged et al. 2011, DiNapoli and Morrison 2017) and Kohala's desiccating winds necessitate windbreak infrastructure (Ladefoged et al. 2003). The modeling work of Lee et al. (2006) suggests mechanisms by which variations in rainfall, temperature, and biogeochemical processes determine spatio-temporal patterns of 'uala (sweet potato, Ipomea batatas) crop growth and long-term development within the Kohala field system where it was a key staple. On the ground, field system restoration efforts indicate climatic gradients and specific cultivation practices such as mulching strongly influence yields of 'uala (Kagawa and Vitousek 2012, Lincoln et al. 2017, Marshall et al. 2017).

\section{'Uala as the lens for exploring seasonal cultivation}

'Uala as a key staple crop in the rain-fed field systems across Hawai $i$, enabled population expansion into regions too arid for other staple crops (Yen 1974, Coil and Kirch 2005). Ethnographic evidence indicates 'uala planting across Hawaiian drylands was closely associated with the onset of rains; planters were acutely attentive to the skies (Pukui 1983, Anonymous 1922 as cited in Trapp 2003), with documented agricultural prayers appealing to deities of rains and clouds (Solis 1999). Across Hawai'i, 'uala was planted with vegetative slips (e.g., Malo 1951, Kamakau 1976, Handy 1940), suggesting planters had ready access to cuttings to establish new fields at the onset of rains. 'Uala is the fastestmaturing of the Hawaiian planter's staple crops, yielding tubers as early as three months (Handy 1940), so hardy and fast-growing that it was referred to as "the food that ends the famine" (Pukui 1983:946). Given the importance of this crop in dryland agriculture, its association with seasonal rains and planting, and its rapid maturation, 'uala provided us an ideal lens for modeling seasonal cultivation in dryland systems.

\section{METHODS}

\section{General approach}

To address our objectives, we analyzed gridded climate data for Hawai'i (Giambelluca et al. 2013, 2014), focusing on regions defined by Ladefoged et al. (2009) as belonging to the Kohala, Kona, and Ka'u field systems. We compared climate means and seasonality indices across the three field systems as aggregated values and as maps to visualize spatial patterning. We then identified and applied monthly climate thresholds to classify periods and locations amenable to cultivation of 'uala. We used these to compare monthly cultivation potential across the three field systems as maps and graphs, which illustrate differences in the start and length of the growing season in different locations across the field systems.

\section{Location and nature of Hawai i Island dryland field systems}

Kohala is located on the leeward slopes of the northern part of the island, Kona is at the western extent of the island, and $\mathrm{Ka}$ ' $\overline{\mathrm{u}}$ is in the south (Fig. 1). A fourth dryland system, the Waimea field system, between Kohala and Kona, is unique in that it exists further inland than the others and includes irrigation features (see Clark 1986, McIvor and Ladefoged 2018). Such uniqueness makes direct comparison between Waimea and the other three field systems difficult, and here we focus on the purely rain-fed

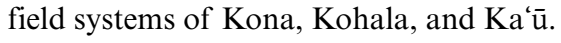

Fig. 1. Map of the rain-fed Kohala, Kona, Ka' $\bar{u}$, and Waimea field systems' extents depicted in Ladefoged et al. (2009) with elevation-based hillshade (State of Hawai'i Office of Planning 2003) and ahupua'a boundaries (Office of Hawaiian Affairs 2009).

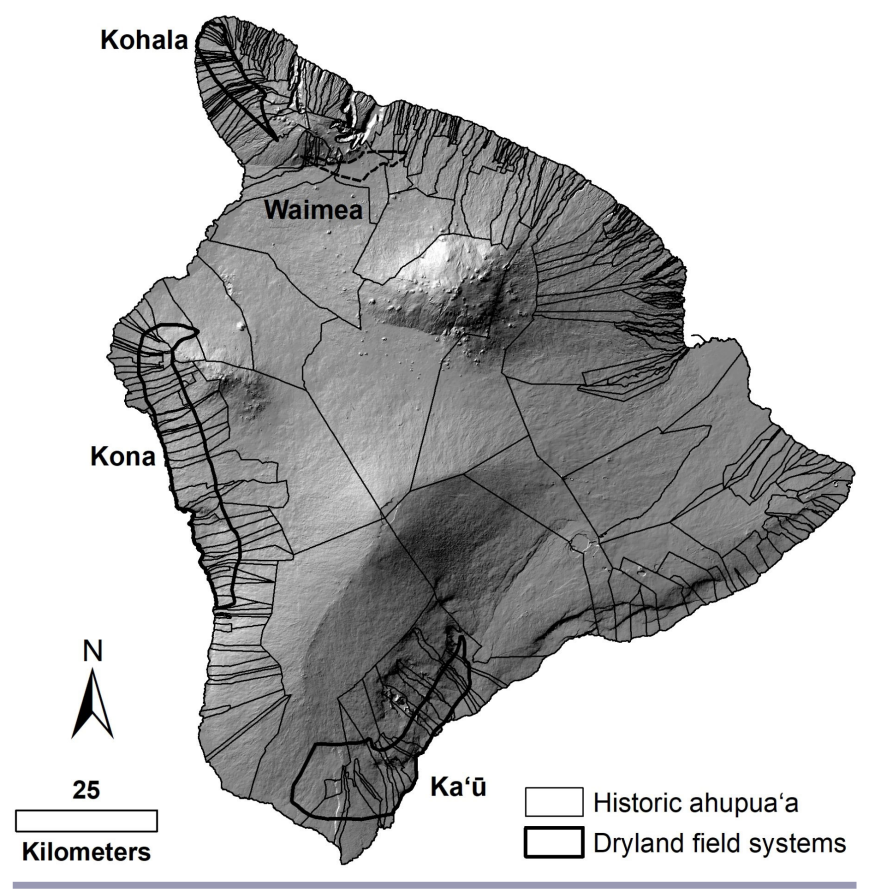

The Kohala field system is located across a $\sim 60 \mathrm{~km}^{2}$ zone on the leeward (western) slopes of the Kohala peninsula of north Hawai' $i$. The field system runs from near the coast at the northern extent of the system to $\sim 900 \mathrm{~m}$ in the south and today remains largely in cattle pasture. The Kona field system spans nearly 150 $\mathrm{km}^{2}$ in intensified agriculture, with another $150 \mathrm{~km}^{2}$ in sparser development. Like Kohala, the Kona field system reaches the coast in some locations, while intensive cultivation extends up to 
$\sim 650 \mathrm{~m}$. Above this, an agroforestry zone extends up to $\sim 900 \mathrm{~m}$; a unique distinction of the Kona field system is this spatial demarcation of cultivation zones (Kelly 1983, Lincoln and Ladefoged 2014). The Ka' $\mathrm{u}$ field system is situated at the southern extent of the island, though its exact scale is unclear because of large-scale alteration by plantation agriculture and few archaeological investigations. Predictive modelling suggests that the system extends across an area roughly measuring over 300 $\mathrm{km}^{2}$, from the coast to at least $\sim 800 \mathrm{~m}$ (Ladefoged et al. 2009).

\section{Climate datasets}

We analyzed climate of the Kohala, Kona, and Ka ù dryland field systems using mean annual and mean monthly gridded data from the Rainfall and Evapotranspiration Atlases of Hawai' $i$ (Giambelluca et al. 2013, 2014). To facilitate climate data extraction, we created a single contiguous polygon for each of the field systems based on the model of Ladefoged et al. (2009). Climatic datasets $(250 \mathrm{~m}$ spatial resolution raster files) were clipped to these modified field system boundaries. The contiguous units contain potentially cultivable lands with substrates deemed too young $(<4 \mathrm{ky})$ for cultivation and pu'u (hills) that slightly increase the maximum elevation beyond the 900 m elevation cutoff used by Ladefoged et al. (2009) to define the field systems. In short, the resultant field system boundaries were more inclusive than those created by Ladefoged et al. (2009). We also note that the recently published rainfall data (Giambelluca et al. 2013) have lower values and slightly different contours than the rainfall dataset (Giambelluca et al. 1986) used by Ladefoged et al. (2009), which is no longer publicly available. Climatic data were summarized and compared as maps, kernel density plots, and time plots (boxplots). Our analysis focused on climatic variables likely to influence cropping within each system, specifically mean annual and seasonal patterns of rainfall $(\mathrm{P})$, solar radiation, cloud cover, air temperature, humidity, wind speed, and modeled Penman-Monteith potential evapotranspiration (PET, Monteith 1973). We calculated mean annual and mean monthly ecosystem aridity indices as PET/P from the annual and monthly grids of PET and P. Seasonality indices for both rainfall and aridity were calculated from the mean monthly grids as coefficient of variation (CV) and as wet season centroid and spread following the methods of Feng et al. (2013). These gridded indices of seasonality allowed us to characterize spatial patterns of moisture reliability. For complete descriptions of the data, see Appendix 1.

\section{Climate thresholding to model crop establishment and growing season}

To further explore how climatic variability shapes mean seasonal patterns of agricultural production, we conducted a thresholding exercise using our clipped monthly grids for the three field systems. We initially defined "cultivable areas" by month, setting criteria of minimum monthly rainfall of $100 \mathrm{~mm}$ and minimum temperature of $21{ }^{\circ} \mathrm{C}$ based on commercial sweet potato requirements of $500-1300 \mathrm{~mm}$ rainfall and $21-28{ }^{\circ} \mathrm{C}$ soil temperature over the entire growing period (Valenzuela et al. 1994). These criteria were overly restrictive, excluding large sections of the field systems where cultivation is known to have occurred, particularly in Kona. We subsequently chose to relax the criteria to focus on 'uala establishment potential because establishment in the first month following planting is a critical period for vegetatively propagated tropical root crops (Wilson 1977). The otherwise drought-tolerant 'uala is sensitive to soil moisture drought in the 40 days following planting of cuttings (Valenzuela et al. 1994) and, in our experience (e.g., Kagawa and Vitousek 2012, Marshall et al. 2017), especially during the first two weeks.

To define appropriate thresholding criteria defined by sufficiently warm and wet monthly conditions, we calculated, for each field system, the total cultivable area resulting from different combinations of mean air temperature and mean rainfall or aridity criteria. More precisely, we set different minima for mean monthly rainfall and air temperature (Fig. A2.1) and analogous thresholds for mean monthly aridity (PET/P, maxima) and air temperature (minima; Fig. A2.2), to identify whether each 250$\mathrm{m}$ pixel was sufficiently wet and warm for a given month. This allowed us to identify threshold pairs that allowed at least $85 \%$ of each field system to support 'uala establishment for at least one month of the year. The final criteria applied across the three field systems were (1) monthly temperature $>18{ }^{\circ} \mathrm{C}$ and monthly rainfall $>90 \mathrm{~mm}$ and (2) monthly temperature $>18{ }^{\circ} \mathrm{C}$ and monthly aridity $(\mathrm{PET} / \mathrm{P})<2.5$. We found these to be reasonably consistent with published values for 'uala and other tropical root crops (Hahn 1977, Wilson 1977, Valenzuela et al. 1994), and these allowed us to visualize mean seasonal patterns of cultivation potential within the field system boundaries. These criteria were then used to generate maps and statistics representing the cultivable area for each month of the year. All analyses were performed in $\mathrm{R}$ version 3.4.1, and scripts and high-resolution versions of figures are available online at https://github.com/ akkagawa/DrylandAg.

\section{RESULTS}

\section{Climate of the Hawai'i Island dryland field systems}

Across the Kohala, Kona, and Ka' $\mathrm{u}$ field systems, elevation ranges from sea level up to $\sim 1000 \mathrm{~m}$, although the Ka' $\overline{\mathrm{u}}$ field system is weighted more toward low elevation (Fig. 2a). Mean annual air temperatures (Fig. 2b) are inversely related to elevation and thus similarly range from $17-24^{\circ} \mathrm{C}$ for all systems but tend to be skewed higher for Ka'ū than Kohala or Kona. Mean annual rainfall is similar across the three systems, each exhibiting strong spatial gradients (Fig. 3a) with values ranging from $580 \mathrm{~mm}$ to $2100 \mathrm{~mm}$ (Fig. 2c). We note annual precipitation of 580-600 mm now roughly defines the lower boundary of cultivation instead of the $750 \mathrm{~mm}$ isohyet used by Ladefoged et al. (2009) because we used different mean annual rainfall gridded datasets (see Methods: Climate datasets). Mean relative humidity ranges from $70-90 \%$ across the field systems, but a slightly greater proportion of the Kona field system experiences higher relative humidity than either Kohala or Ka'ū (Fig. 2d).

Despite similar ranges and profiles for elevation, temperature, rainfall, and humidity for the three systems, sharp differences arise for the climatic variables relevant to evapotranspiration. Cloud frequency is substantially lower for the Kohala field system than either Ka'u or Kona (Fig. 2e). Of the two field systems with higher cloud frequency, Kona is more uniformly cloudy while Ka'u appears to be split into two zones. These differences in cloudiness translate to effects on solar radiation: direct shortwave (solar) radiation is much higher for Kohala than Ka $\mathrm{u}$ u or Kona (Fig. 2f) while diffuse shortwave radiation is highest for Kona (not shown). Mean annual wind speed is also substantially higher in Kohala 
Fig. 2. Kernel density estimates for the Kohala, Kona, and Ka'ū field systems for (a) elevation (m), and mean annual values of $(\mathrm{b})$ air temperature $\left({ }^{\circ} \mathrm{C}\right)$, (c) rainfall $(\mathrm{mm}),(\mathrm{d})$ relative humidity $(\%),(\mathrm{e})$ cloud frequency, (f) incident shortwave radiation $(\mathrm{Wm}-2)$, $(\mathrm{g})$ wind speed $(\mathrm{ms}-1)$, and $(\mathrm{h})$ Penman-Monteith potential evapotranspiration $(\mathrm{mm})$.
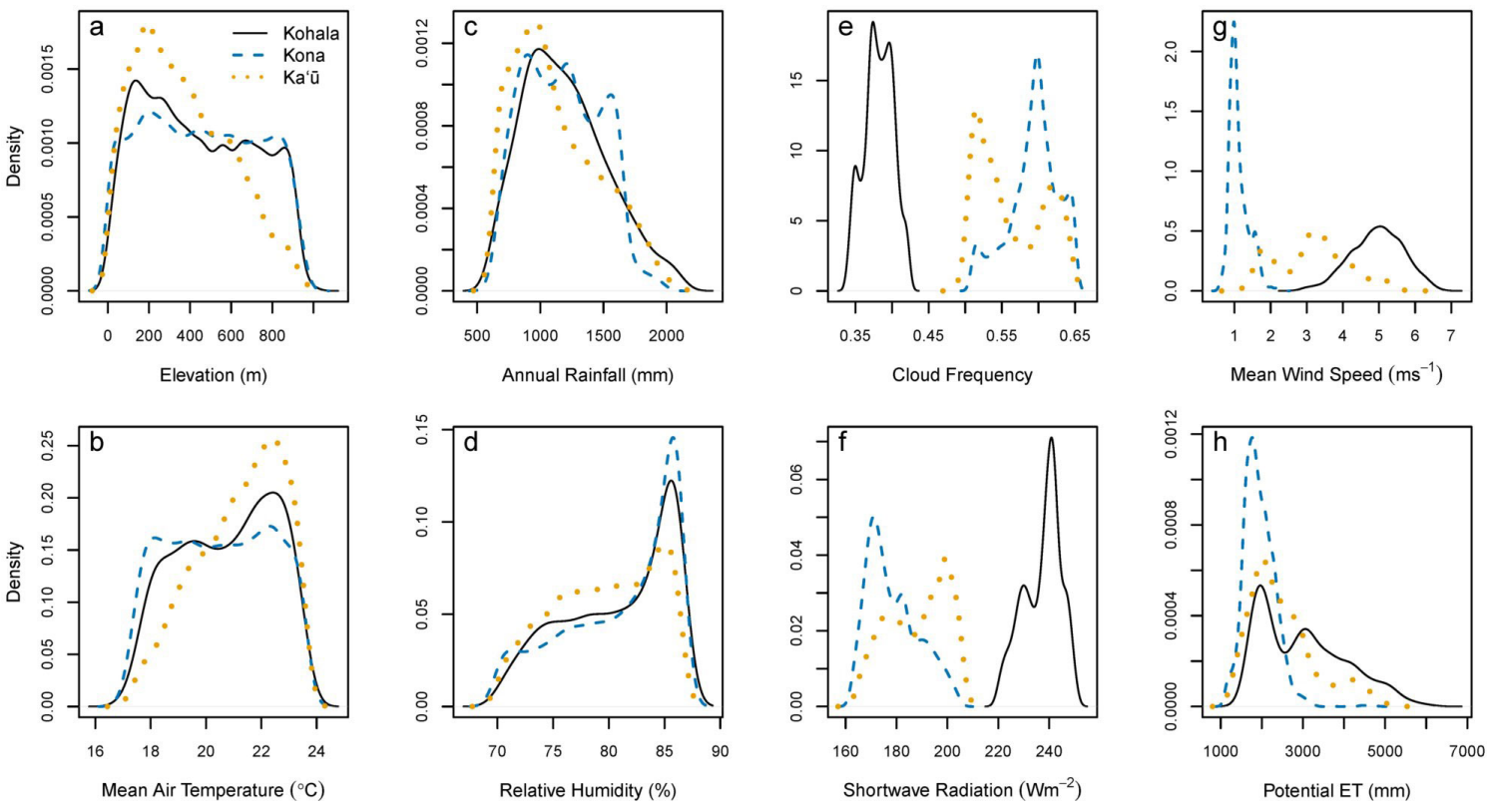

than Kona with an intermediate and broad range of values for Ka'ū (Fig. 2g). The distributions of mean annual PenmanMonteith potential evapotranspiration (PET) overlap for the three field systems, but parts of Kohala see very high PET values, Kona has the lowest PET values (skewed left, right tail), and Ka' $\mathrm{u}$ is intermediate (Fig. 2h).

Although the Kohala, Kona, and Ka'u field systems have similar mean annual rainfall, their respective seasonal patterns of rainfall vary strongly in timing (Fig. $4 \mathrm{a}-\mathrm{c}$ ). For both Kohala and $\mathrm{Ka}{ }^{\prime} \mathrm{u}$, the rainiest months are November-April while for Kona they are June-September. The mapped CV derived from mean monthly rainfall indicates that rainfall seasonality is more spatially variable in Ka' $\mathrm{u}$ than in Kohala or Kona (Fig. 3b), driven largely by coastal areas with low mean annual rainfall and high month-to-month variation (Fig. 3a). The rainy season centroid (Fig. 3c) differs in timing for all three systems, where the rainy season peaks in January for Ka' $\mathbf{u}$, in March for Kohala, and from July to midAugust for Kona. The rainy season timing also appears to vary strongly even within the Kona field system.

Potential evapotranspiration (PET) is elevated during summer months in all three systems, but the magnitude of the annual cycle is small relative to the spatial variation of PET within each system for any given month (Fig. 4d-f). Although small, the annual cycle in PET amplifies aridity (PET/P) in Kohala and Ka' $\bar{u}$ during summer months when higher PET coincides with lower rainfall, while in Kona, it dampens the seasonality of aridity because PET and $\mathrm{P}$ are in phase (Fig. $4 \mathrm{~g}-\mathrm{i}$ ). As with rainfall, spatial patterns of aridity seasonality are relatively even within the Kohala and Kona field systems, while the Ka'u field system includes coastal areas with large month-to-month variability in aridity (Fig. 3e).
Ka'ū's dry season peaks around May-July, Kohala's dry season extends later in the year from May to October, and Kona's dry season predominantly peaks in February-March (Fig. 3f).

Air temperature, relative humidity, and vapor pressure deficit vary along elevational gradients within the field systems more than they vary between the field systems. Across all systems, these variables follow a consistent seasonality (Appendix 3). This spatial and seasonal variability in temperature leads to a seasonally shifting envelope when temperature criteria are imposed. A seasonally shifting envelope is similarly produced when thresholds are imposed for rainfall and aridity given strong spatial gradients (Fig. 3a, 3d) and seasonality (Fig. 4a-c, 4g-i). The intersection of areas defined by these adjustable criteria can be used to identify zones with conditions adequate for cultivation.

Climate-based seasonal establishment and cultivation envelopes In exploring possible temperature, rainfall, and aridity cultivation thresholds (see Appendix 2), we assessed whether climatic thresholds should be defined for each system separately, or if we could impose a single set of conditions for 'uala cultivation to apply to all three systems simultaneously. We found notable differences between systems in thresholds needed to reproduce the Ladefoged et al. (2009) field system boundaries. For example, a lower, more permissive minimum monthly rainfall threshold was required to reproduce the Kona field system delineation compared to Kohala or Ka'ù (Fig. A2.1). On the other hand, when we ran the same analysis for aridity (PET/P), a higher and more permissive maximum aridity was required to reproduce the Kohala field system delineation while the lowest (most restrictive) aridity threshold was possible for Kona (Fig. A2.2). Kona seems marginal when considering only rainfall, but when its lower 
Fig. 3. Spatial variability in rainfall in terms of (a) mean annual value, (b) coefficient of variation (CV, \%) across 12 months as an index of seasonality, (c) rainy season centroid from $0-12$ with January as $0-1$. Spatial variability of aridity as (d) mean annual value, (e) CV, (f) dry season centroid for the Kohala, Kona, and Ka'u field systems.

Mean annual $\mathbf{P}(\mathbf{m m})$

(a)

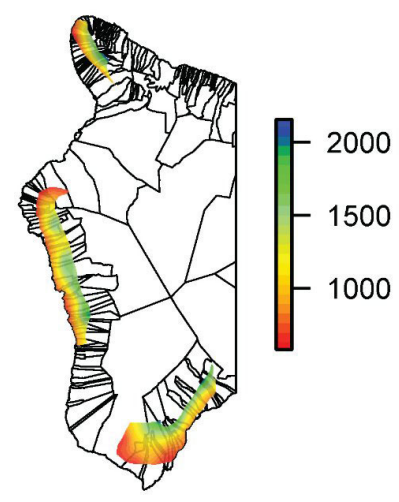

Mean annual PET/P

(d)

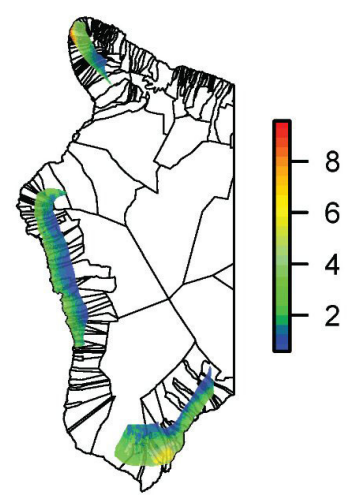

CV of monthly $\mathbf{P}$

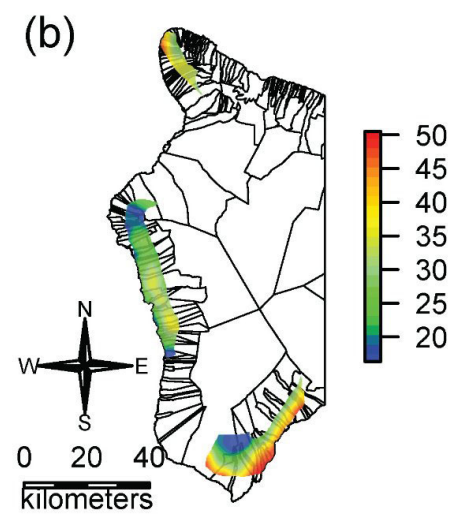

CV of monthly PET/P

(e)

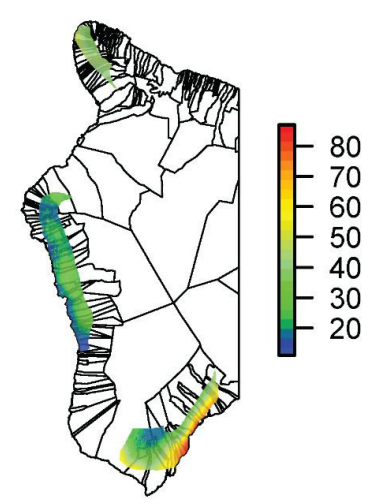

Rainy season centroid (mo) (c)

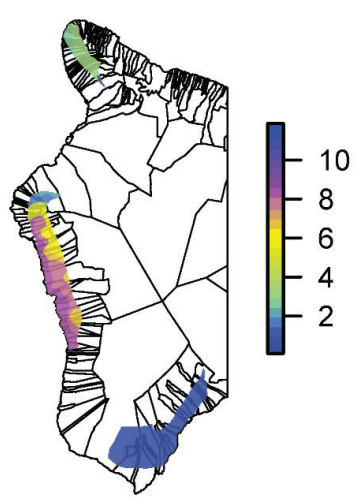

Dry season centroid (mo)

(f)

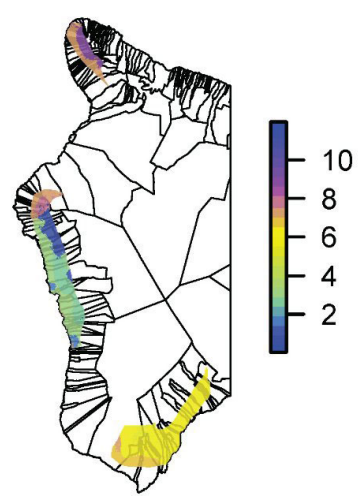

evaporative demand is accounted for via the aridity metric, Kohala becomes the most marginal in terms of water balance. That these different field systems saw cultivation throughout despite the suggested thresholds may reflect differences between the field systems in terms of soil properties related to soil water storage; Kohala has the deepest soils, which may mitigate the atmospheric aridity. We also acknowledge these inferences are sensitive to how we delineate the field systems. For these reasons, we ultimately opted to define a single set of criteria across all three systems for the following analyses.

When we imposed cultivation thresholds for mean monthly temperature $\left(\mathrm{T}_{\text {mean }}>18^{\circ} \mathrm{C}\right)$ and rainfall $(\mathrm{P}>90 \mathrm{~mm})$, cultivation envelopes shifted within the field systems from month to month, highlighting areas in each system suitable for planting and cultivation (Fig. 5, maps). This resulted in strong variation in the timing of optimal conditions for planting and variation in the hypothetical growing season length for different areas within each field system. The patterns shifted slightly when an aridity threshold (PET/P < 2.5) was used instead of rainfall (Fig. 6).
Variation in seasons for planting

Each field system exhibits a distinct seasonal cultivation cycle. Analysis of rainfall-based establishment envelopes for $\mathrm{Ka}^{\mathrm{t}} \mathrm{u}$ and Kohala suggest little opportunity for summer planting, but this increases rapidly in the late fall and continues through winter (Fig. 5, line graph). In Kona, planting potential is low in winter but increases in spring, steadily increases through summer, and rapidly declines in the fall. These patterns in timing are similar regardless of whether cultivation envelopes are defined by rainfall (Fig. 5) or aridity (Fig. 6), but the magnitude of seasonality captured by coefficient of variation (CV; see Table 1) differs considerably; it is reduced by nearly $60 \%$ with use of an aridity criterion. Among the field systems, the CVs of cultivable area are large but variable, reflecting seasonal constraints to planting within each field system. Yet complementarity in the seasonal timing of cultivation is such that $\mathrm{CV}$ is more than halved when these systems are considered in aggregate (Table 1).

Seasonal patterning of establishment and cultivation is also evident at finer scales within each field system. Ahupua' $a$, political units generally spanning elevational gradients, are often described 
Fig. 4. Intra-annual (seasonal) variation within the Kohala, Kona, and Ka'ū field systems for rainfall (a-c), Penman-Monteith potential evapotranspiration (PET, d-f), and aridity (PET/P, g-i)

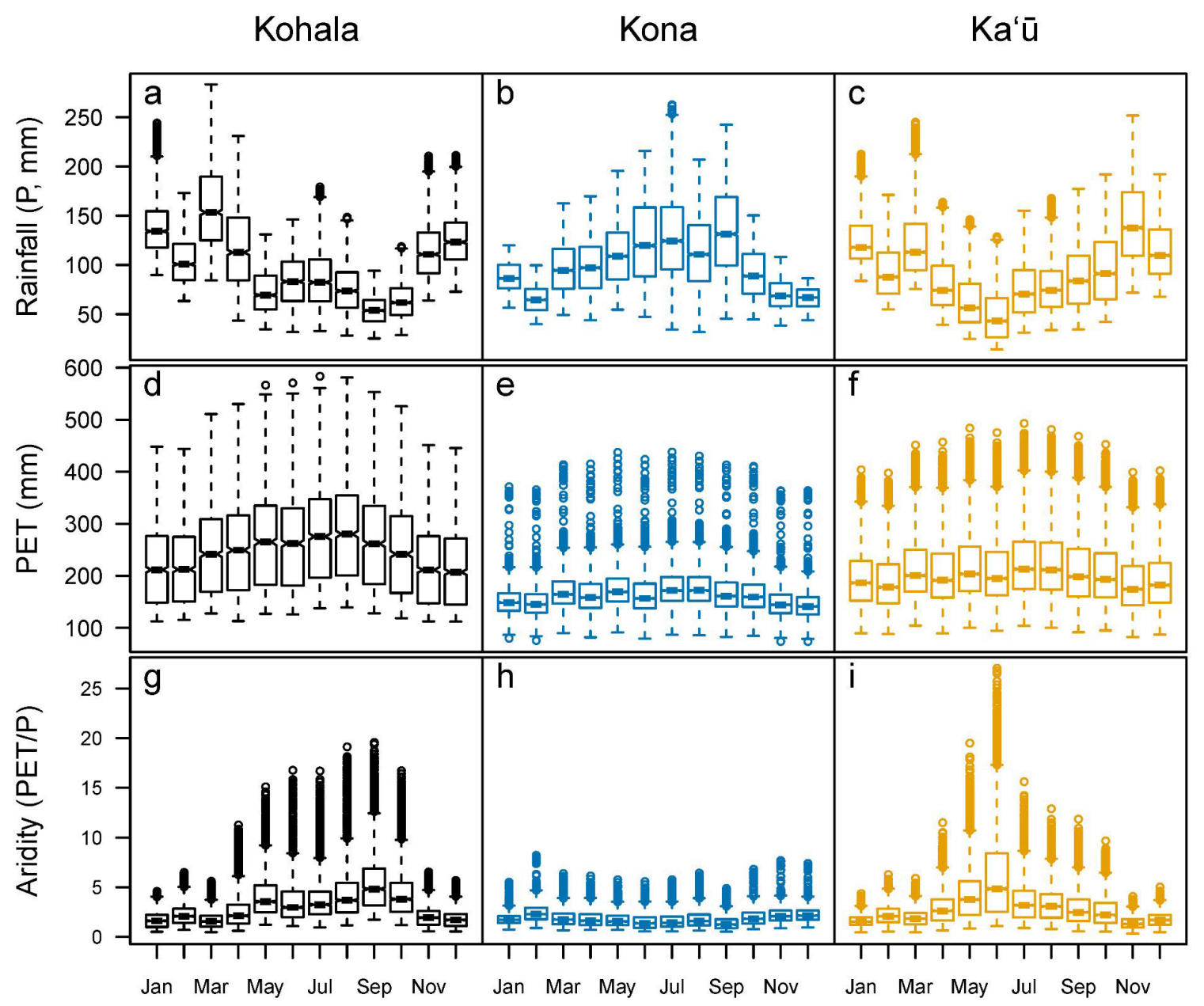

Table 1. Monthly cultivable area summarized as mean hectares and percentage of each field system and coefficient of variation as an index of monthly variation (seasonality) over the annual cycle, expressed here as a percent. Areas were estimated on a pixelby-pixel basis when criteria were imposed for monthly temperature and moisture conditions (rainfall, $\mathrm{P}>90 \mathrm{~mm}$ and aridity, $\mathrm{PET} / \mathrm{P}<2.5$ ) for each field system individually and in aggregate.

\begin{tabular}{|c|c|c|c|c|c|c|}
\hline & \multicolumn{6}{|c|}{ Mean Monthly Area Suitable for Sweet Potato Establishment } \\
\hline & \multicolumn{3}{|c|}{$\mathrm{T}_{\text {mean }}>18^{\circ} \mathrm{C}$ and $\mathrm{P}>90 \mathrm{~mm}$} & \multicolumn{3}{|c|}{$\mathrm{T}_{\text {mean }}>18^{\circ} \mathrm{C}$ and $\mathrm{PET} / \mathrm{P}<2.5$} \\
\hline & Area (ha) & Area $(\%)$ & C.V. & Area (ha) & Area $(\%)$ & C.V. \\
\hline & & 300 & 58.5 & 3454 & 347 & 46.7 \\
\hline Kona & 14,552 & 8.9 & 74.0 & & 62 & 30.0 \\
\hline Ka'ū & 15,8 & 42.2 & 57.7 & & 48. & 36.6 \\
\hline Total & 34,356 & 40.3 & 23.5 & 44,744 & 48.3 & 19.7 \\
\hline
\end{tabular}

as being self-sufficient and are a useful unit from which to consider local food resources. The seasonal cultivation envelopes for Kona and $\mathrm{Ka}$ ' $\mathrm{u}$ generally expand and contract with elevation along the ahupua'a, suggesting that complementary opportunities for cultivation occur at coastal and upland locations throughout the year (Fig. 5, maps). In contrast, the cultivation envelope in Kohala moves obliquely to the ahupua' $a$ such that the northern units offer better planting potential in the winter while the southern units are more amenable in summer.

\section{Variation in growing season length}

Within each system, opportunities for planting and production range from marginal to highly consistent. Some areas appear to be sufficient for crop establishment but have a growing season that is too short for even three-month 'uala production. Meanwhile, other areas are sufficiently moist and warm for more than nine months of the year (Fig. 7, a-f). Areas with longer growing seasons might have been less prone to seasonal drought, produced multiple crops per year, or enabled successful harvests of thirstier crops such as kalo (taro, Colocasia esculenta). Regardless, they would have been important and more desirable lands. In the Kona and $\mathrm{Ka}$ ' $\mathrm{u}$ field systems, these more reliable areas are distributed across multiple ahupua' $a$ fairly evenly, while within the Kohala system, they are clustered in the central 
Fig. 5. Maps of seasonally shifting optimal conditions for 'uala (sweet potato, Ipomea batatas) establishment in the Kohala, Kona, and $\mathrm{Ka}$ u field systems using monthly criteria Tmean $>18^{\circ} \mathrm{C}$ and $\mathrm{P}>90 \mathrm{~mm}$. Monthly data are binned for visual simplicity while the graph below indicates percentage of each field system that is cultivable in each month.
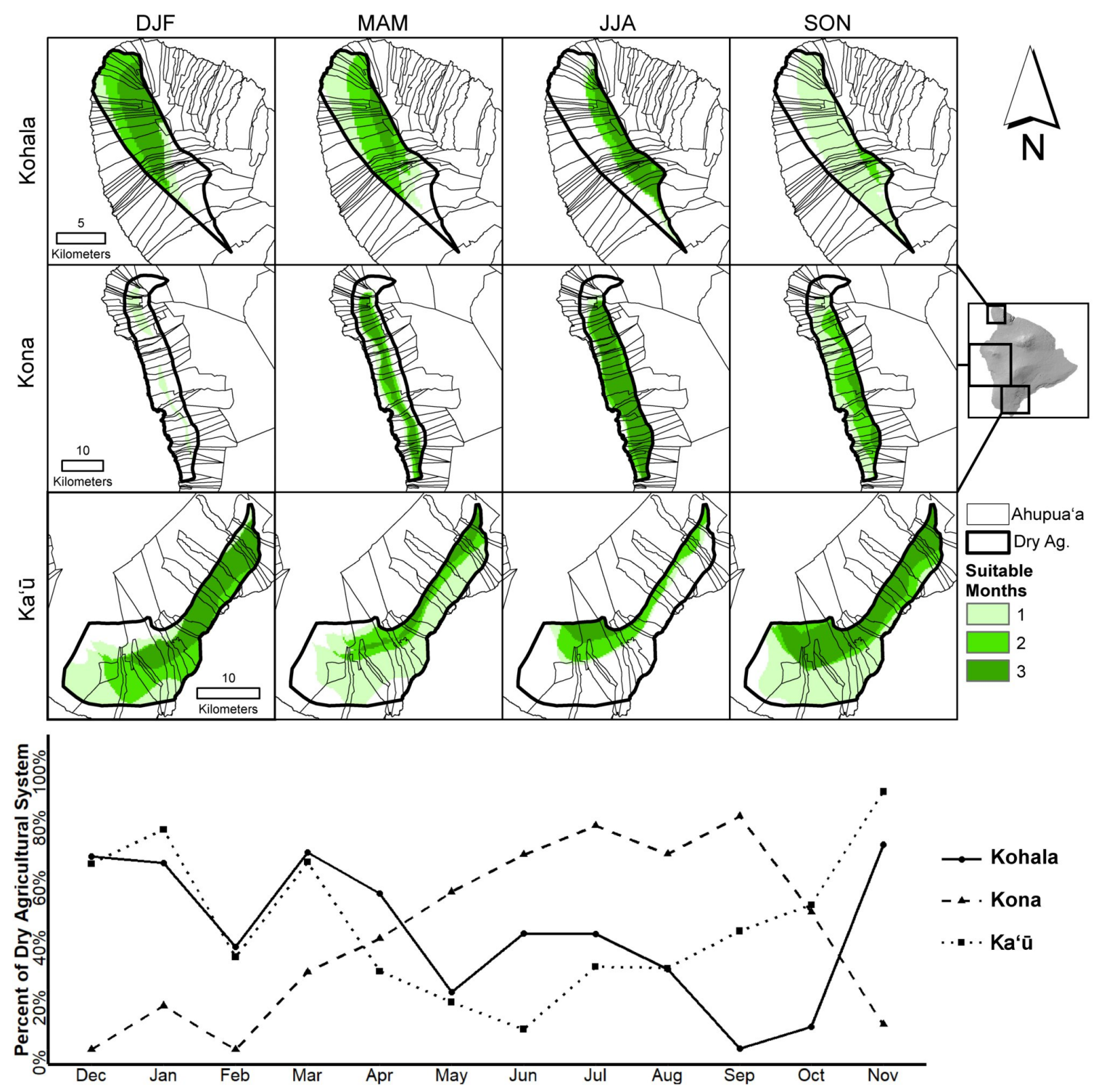

ahupua'a (Fig. 7, a-f), a result consistent with previous research (Ladefoged et al. 2008).

Thresholding with aridity produced different spatial patterns than thresholding with rainfall and affected each field system differently (Fig. 7, g-i). In Kohala, where high solar radiation and wind speeds drive high potential evapotranspiration (PET), imposing an aridity threshold decreases potential cultivation in lower-elevation ahupu' $a$ and slightly increases it in cooler uplands. In $\mathrm{Ka}^{\prime} \mathrm{u}$, where wind speeds and solar radiation are lower, imposing an aridity threshold increases potential cultivation in western (leeward) areas while depressing it to the southeast. Finally, Kona, where wind speeds are low and cloud cover is high and seasonally in sync with the rainy season, defining cultivation with aridity versus rainfall criteria greatly increases potential cultivability across the whole system.

\section{DISCUSSION}

We demonstrate the dryland field systems of Hawai'i Island differ substantially despite superficial similarities in elevation and mean annual rainfall. Differences in (1) evapotranspiration drivers of wind speed, cloud cover, and solar radiation and (2) rainy season timing contributed to (3) strong summer aridity for field systems of Kohala and $\mathrm{Ka}$ 'ū relative to Kona. By imposing temperature and moisture criteria for 'uala establishment, we identified (4) spatio-temporal patterns of planting potential, which gave rise to 
Fig. 6. Maps of seasonally shifting optimal conditions for 'uala (sweet potato, Ipomea batatas) establishment in the Kohala, Kona, and $\mathrm{Ka}{ }^{\top} \mathrm{u}$ field systems using monthly criteria Tmean $>18^{\circ} \mathrm{C}$ and PET/P $<2.5$. Monthly data are binned for visual simplicity while the graph below indicates percentage of each field system that is cultivable in each month.
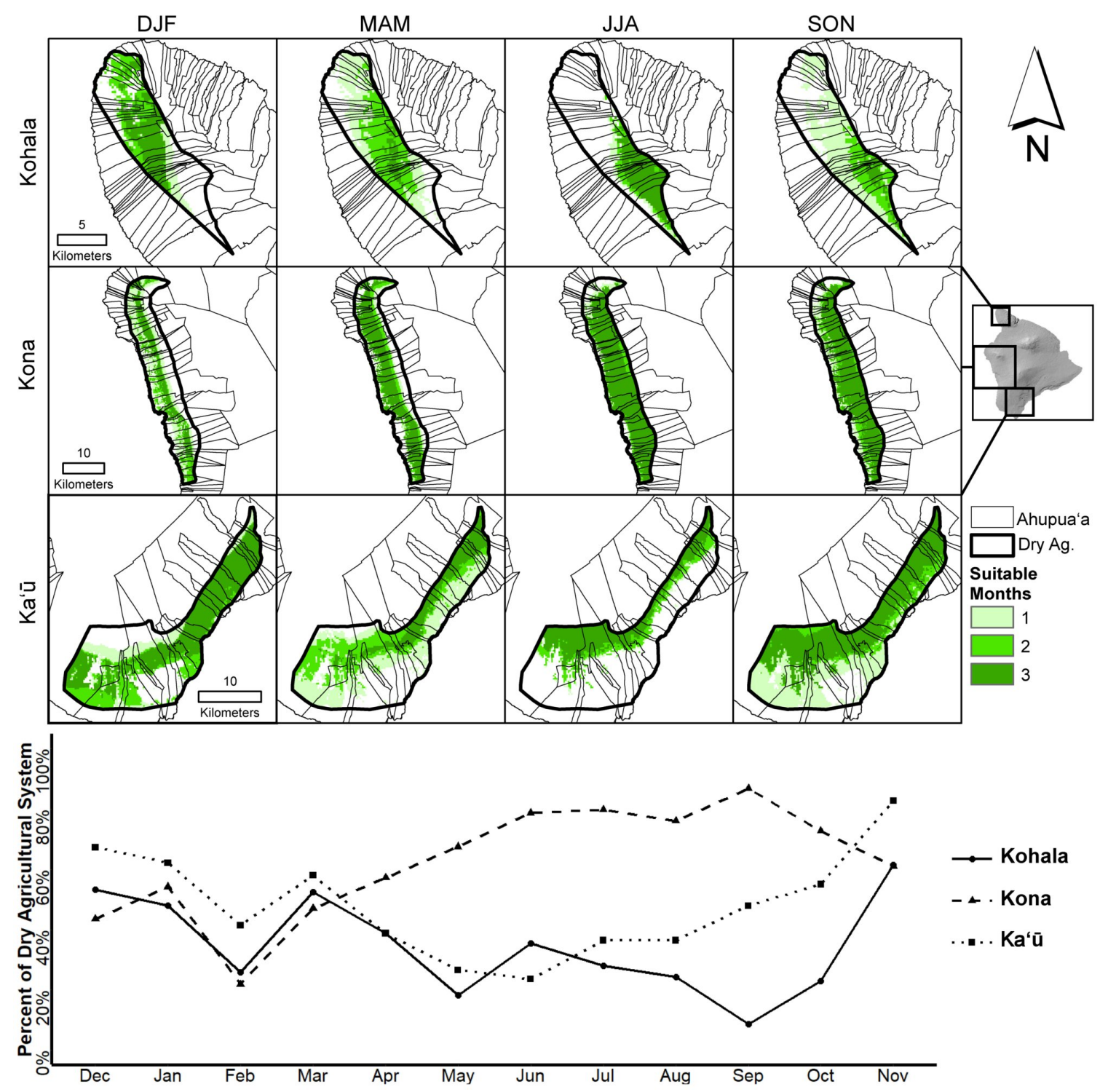

(5) variable spatial patterns of growing season length within and between field systems. At the island-level, seasonality of planting and production in the three systems is largely complementary in time (Table 1, Fig. 5). We observed that the apparent seasonality of planting and production also varied within ahupua' $a$, with planting windows moving up and down elevational gradients. For the Kona and $\mathrm{Ka}^{\prime} \overline{\mathrm{u}}$ systems, this resulted in all ahupua'a experiencing similar patterns with coastal zones characterized by a shorter growing season than upland or midelevation zones. For Kohala, the envelope for optimal growing conditions shifted laterally across multiple ahupua' $a$ such that more southern, higher elevation ahupua'a could have been planted later (Fig. 6). Thus, an ahupu' $a$ in Kona and $\mathrm{Ka}$ 'ù might have sustained production across the annual cycle, whereas in Kohala, more cross-ahupua' a coordination may have been necessary to maintain steady access to crop production.

Although lessons learned in the intensively researched Kohala dryland field system have transformed our understanding of Hawaiian agriculture, important work lies ahead to truly understand complexities in the operation and development of indigenous cultivation systems. Our own analysis was enabled by a comparative approach, the availability of gridded climate data (Giambelluca et al. 2013, 2014), novel metrics for summarizing tropical climatic seasonality (Feng et al. 2013), and applying the lens of 'uala, a short-cycle tropical root crop and known staple in 
Fig. 7. Cumulative months meeting 'uala (sweet potato, Ipomea batatas) establishment criteria based on $(\mathrm{a}-\mathrm{c})$ temperature and rainfall (Tmean $>18{ }^{\circ} \mathrm{C}$ and $\left.\mathrm{P}>90 \mathrm{~mm}\right),(\mathrm{d}-\mathrm{f})$ temperature and aridity (Tmean $>18^{\circ} \mathrm{C}$ and $\left.\mathrm{PET} / \mathrm{P}<2.5\right)$, and the difference of these $(\mathrm{g}-\mathrm{i})$.
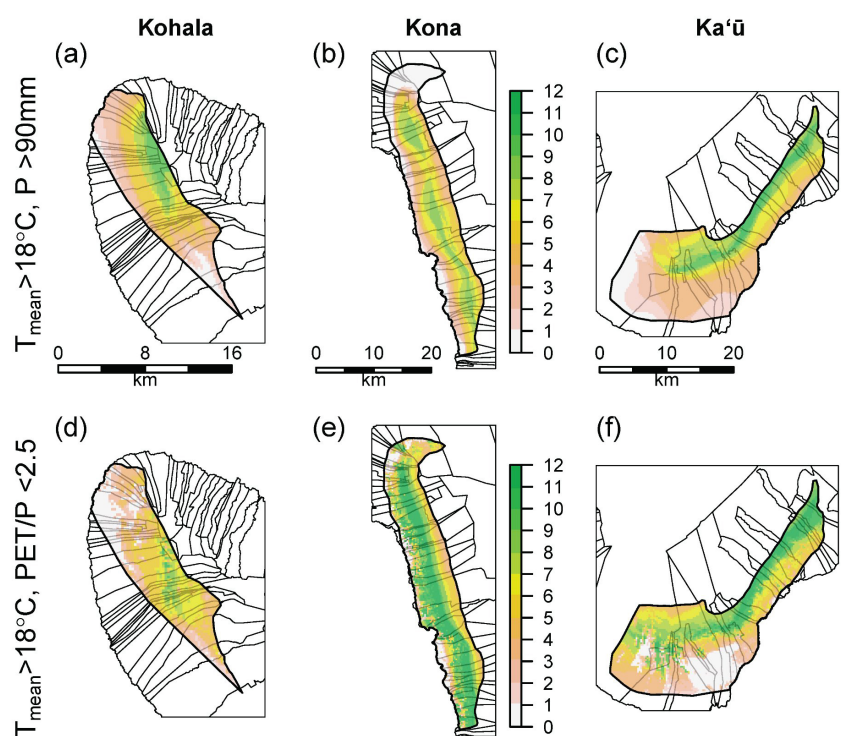

(e)

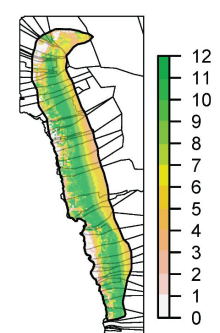

(f)

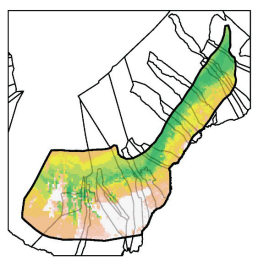

(h)

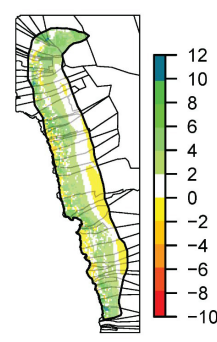

utilized topography and substrate heterogeneity to concentrate run-on and intermittent surface flows and identified the potential for fog drip to feed lower elevation seeps (Stock et al. 2003, Kirch 2014). We know less about the nature of similar features in the dryland systems on Hawai' $i$ Island and to what extent they would have increased production.

\section{Variations in infrastructure}

While interannual rainfall variability shapes production across these dryland systems (Ladefoged and Graves 2000, Ladefoged et al. 2008, 2009, 2011, DiNapoli and Morrison 2017), evaporative losses also constrain arid ecosystem productivity. This is especially evident when comparing the dryland field systems: Kona is not more suitable for cultivation because it is rainier, but because wind speed and solar radiation driving ET losses are lowest. The drier nature of the Kohala and $\mathrm{Ka}$ ' $\mathrm{u}$ field systems and even parts of the Kona field system, where areas of low cultivation potential are evident, suggest not only that significant gains could be realized by ET-reducing investments, but that they might even be necessitated over time. In situ field management that increases capture and storage of soil moisture, minimizes moisture loss, and extends periods of sufficient moisture would extend the growing season and increase staple root crop yields. Mulching with organic material was an important practice in all the systems for both moisture conservation and nutrient inputs (e.g., Lee et al. 2006, Lincoln and Vitousek 2016). Rock mulches, too, likely improved 'uala yields (see Marshall et al. 2017) by reducing evaporation of soil moisture (Allen 2004, Graf et al. 2008) and improving soil nutrient availability, as is suggested from work in Rapa Nui (Vitousek et al. 2014). Furthermore, seasonal fallowing and shifting of quickly-maturing crops such as 'uala would benefit the productive capacity and stability of these systems.

In these dryland systems, the most visible remnant of agricultural infrastructure is a series of low earthen and stone linear embankments also known as kuaiwi, agricultural walls, or field ridges. These are present in each of the field systems but differ in alignment. In Kohala, the primary embankments are situated perpendicular to the prevailing wind direction and along elevation contours. Kohala's strong winds and high solar radiation suggest windbreak infrastructure associated with these linear embankments was, if not simply necessary, at least a very good return on investment for reducing physical damage and evaporation and providing mulch (see Kagawa and Vitousek 2012, Ladefoged et al. 2003, Marshall et al. 2017, Lincoln et al. 2017). In more moderately windy Ka' $\bar{u}$, primary embankments similarly run perpendicular to the prevailing wind with an upslopedownslope orientation, although minor embankments are orthogonal to this. In contrast to Kohala, the embankment features in much less windy Kona are aligned parallel to both the dominant diurnal winds and the slope (see Lincoln and Vitousek 2017). In this case, the west-southwest orientation of the Kona field embankments may be associated less with ET reduction than with minimizing shading of staple crops in Kona's cloudier environment (Fig. 2f).

Further, an explicitly hydrological approach considering both moisture inputs (rainfall), losses (evapotranspiration, infiltration, or runoff), and solar energy may strengthen our understanding of how infrastructure influenced crop production within the field systems. For instance, in Kohala, interception of the wind-borne 
mist on embankments leads to increased soil moisture on the windward side of the wall and decreased soil moisture on the lee side (N. Lincoln, unpublished data). Both windward and leeward faces are affected by ET losses from winds and solar radiation, but these are either similar on both faces or greater on the western lee side such that the moisture pattern produced by differential mist deposition is maintained/reinforced. In the northwestern section of the Ka' $\bar{u}$ field system, preliminary data hint that the pattern is reversed, with higher (lower) soil moisture on the leeward (windward) faces of the embankments (Menzies, Robins, Quintus, et al. 2017, unpublished manuscript). Here, we believe moderate wind speeds result in similar rainfall inputs to the two faces, and differential ET losses (higher windward and lower leeward) explain the moisture patterning. This subtle heterogeneity hints at the role of taller vegetative windbreaks and other wall configurations in creating microclimates for cultivation (Handy 1940, Handy et al. 1972). Current restoration efforts in the dryland systems (see Kurashima et al. 2017, Marshall et al. 2017) provide opportunities to test these working hypotheses on field infrastructure: microclimate interactions.

\section{System integration}

The three field systems coincide with a high density of ahupua'a, or smaller land divisions, indicative of greater territorialization within these production systems. Ahupua'a boundaries on the more gradual slopes of Hawai'i Island delineate sociopolitical units organized around the availability of natural resources and labor (Gonschor and Beamer 2014). Within Kohala, Ladefoged et al. (2008) argue that such ahupua a delineation represents the most efficient allocation of resources for surplus production, and a general strategy toward increased managerial oversight and system integration has been suggested for Kona (Allen 2004).

The degree and nature of spatial variation in optimal cropping conditions in Kohala, in conjunction with previously recorded interannual variation (Ladefoged et al. 2008, DiNapoli and Morrison 2017), may have motivated increased coordination across ahupua'a boundaries, be that coerced or not, as times of need in some divisions coincide with times of plenty in others. Such a situation appears less likely to be the case in Kona or Ka' $\bar{u}$ based on the seasonal patterning of cultivable lands. In contrast, inter-ahupu' $a$ coordination in these locations might have been driven only by interannual production variation between ahириа' $a$, but knowledge of this situation is lacking for these two regions.

Even with clear climatic differences, the temporal development of these systems was markedly similar, though more data are available for Kohala and Kona than for $\mathrm{Ka} \mathrm{a}^{\mathrm{u}}$. Initial land use might have occurred as early as the 13th century in Kohala (Ladefoged and Graves 2008), but initial agricultural investments in the built landscape do not appear to have occurred in any of the three until the 15th century and later (Allen 2004, TomonariTuggle 2006, Ladefoged and Graves 2008, McCoy et al. 2017). From this point, and especially after the 16th century, a period of continuous agricultural investment is visible but spatially variable. For Kohala, Ladefoged and Graves (2008) note that infrastructure construction was likely most intensive after AD 1650, a situation supported by recent Bayesian analysis (Dye 2011a,b). In Kona, initial investments in infrastructure were perhaps made in the 15 th century (Allen 2004) and continued until European contact
(McCoy et al. 2017), with Tomonari-Tuggle (2006) proposing a particularly intensive period around AD 1750. The few dates from $\mathrm{Ka}$ 'u are consistent with Kohala and Kona, with initial infrastructure built in the 16th century and continuing up to European contact (Bennicas, Hicks, Quintus, and MonizNakamura 2017, unpublished manuscript).

In Kona and Kohala, early investments are thought to have been associated with domestic production (Allen 2004, Field et al. $2011 a, b)$, perhaps related to the introduction of 'uala, where topdown management of production was limited. To some extent, this is seen in the localized nature of infrastructural improvements that do not span across individual political units. Over time, especially after AD 1650, there is an increase in the construction of heiau (elite temple complexes), taken by some as evidence of increased oversight (McCoy et al. 2011, McCoy 2014, see also Phillips et al. 2015). This is met with more expansive construction of infrastructure that could be accomplished more efficiently through regional coordination (Allen 2004, Lincoln and Ladefoged 2014). Given these related developments, the 17th century and later saw the rise and maintenance of the archaic state of Hawai'i, and the surplus extraction mechanisms that accompanied a polity of that size (see Kirch 2010, Hommon 2013).

Based on the foregoing, we envisage a situation wherein several practices associated with moisture management were developed in each of the three field systems in response to local environmental characteristics. These innovations focused on the domestic sphere and developed from the bottom-up (see Erickson 2006). Over time, and as the power of individual polities spread throughout the leeward districts and the entire Island of Hawai $i$, these systems were integrated through redistribution or coordination to enhance food security and surplus production as populations grew. That the initial royal centers of the leeward districts were in Kona (Kirch 2010) might relate to the high productivity and stability of the area, as demonstrated here, relative to Kohala and $\mathrm{Ka}$ ' $\mathrm{u}$. Though the creation of the royal center is associated with 'Umi after the unification of the island (Cordy 2000), and the entire island was theoretically under the control of a single polity, proximity ensures more efficient control. Proximity to the production of the Kona field system may have initially aided in the collection of surplus or management of a larger population that was reliant on the productivity of the Kona field system. The complementary seasonality of production of the three systems discussed here would indicate that consolidation and increased coordination (through coerced redistribution or cooperative exchange) could create more stable political hierarchies. This characteristic of these systems might have facilitated increased security enabling increased wealth asset investment and the development of both a staple and wealth finance political economy that underpinned the polities on the island. However, this trajectory would make populations more vulnerable when island-wide polities broke down.

\section{Supporting food system restoration and cultural practice}

This analysis was inspired and informed by community-driven efforts to restore Hawaiian agricultural systems and cultural practice. Recent revival of traditional calendars such as the Hawaiian kaulana mahina (Tsuha 2007) have increased practice of kilo 'āina, a form of citizen science focused on locale-specific 
phenology and linkages of physical and biological cycles. It has roots in and is largely owned and controlled by members of the Hawaiian community engaged in revitalizing traditional practice. It is also a key means for building community capacity to adapt to climate change (Nu'uhiwa, Lilly, Nobrega-Olivera, and Huihui 2016, unpublished manuscript). We suggest that as networked observations of citizen scientists increase, spatio-temporal modeling approaches like that presented here can not only provide retrospective insight, but also complement grassroots restoration efforts and phenological observations. Analyses such as these could be part of an integrative historical ecology approach such as that described by Kurashima et al. (2017) for Kūāhewa within the Kona field system. Such an approach that leverages modern datasets while focusing on questions of value to community practitioners may simultaneously support research into social processes of interest to archaeologists, as well as community efforts to restore traditional food production systems, traditional practice, and community well-being.

\section{Study limitations and future opportunities in modeling dryland crop production}

In this analysis, we assume contemporary climatological means sufficiently represent conditions during the period of active cultivation (until the decline of the systems in the 1800s). Yet Hawai $i$ rainfall has fluctuated through the past five centuries (Diaz et al. 2016), and leeward Hawai'i has experienced strong declines in dry season rainfall over the last decades (Frazier and Giambelluca 2017). Future work should consider how spatial rainfall patterns affected by El Niño and longer-term climate cycles (Frazier, Giambelluca, and Diaz 2012, unpublished manuscript) influence dryland production and island-wide regional socio-political developments. We also recognize that climate alone does not determine crop production, and numerous other variables influence yields. The authors are currently working with a sweet potato crop model (Setiyono et al. 2011) to quantify crop production potential and patterns in a more rigorous manner. Although indigenous cropping systems are usually a diverse assemblage of cultivars and species, working with sweet potato is an important first step.

\section{CONCLUSION}

Our study of three Hawai i Island dryland field systems demonstrates how climatic variability within and across the systems shapes seasonal cultivation potential, which could have motivated coordination across multiple scales to maintain steady food supply. Strong differences in aridity between the systems suggests infrastructural innovations were oriented more toward reducing moisture loss in drier systems of Kohala and Ka' $\mathrm{u}$, while this does not appear to be a priority in cloudier Kona. For these field systems, the seasonality of rainfall, aridity, and temperatures dictate both the start and length of the growing season with implications for crop establishment, yields, and exchange in different locales. It is our hope that this study stimulates further observation, experimentation, restoration, and discussion on how dryland field systems functioned as integrated units of agricultural production.

Responses to this article can be read online at: http://www.ecologyandsociety.org/issues/responses. php/10369

\section{Acknowledgments:}

This collaboration was initiated following the Workshop on Using High Resolution Paleoclimate Reconstructions Since AD 1500 in Support of Research on Environmental/Societal Change in Hawai i in June 2017, sponsored by the Pacific Islands Climate Change Cooperative and the University of Hawai i at Mānoa College of Social Sciences through the Department of Geography and the Department of Anthropology. We thank Henry Diaz and meeting participants for the exchanges motivating this analysis, and we thank the kilo 'anina practitioners across the Hawaiian community who drew our attention to the importance of context and seasonality.

\section{LITERATURE CITED}

Allen, M. S. 2001. Gardens of Lono: archaeological investigations at the Amy B. H. Greenwell Ethnobotanical Garden, Kealakekua, Hawai $i$. Bishop Museum Press, Honolulu, Hawai'i, USA.

Allen, M. S. 2004. Bet-hedging strategies, agricultural change, and unpredictable environments: historical development of dryland agriculture in Kona, Hawaii. Journal of Anthropological Archaeology 23(2):196-224. http://dx.doi.org/10.1016/j.jaa.2004.02.001

Clark, J. T. 1986. Waimea-Kawaihae, a leeward Hawaii settlement system. Dissertation. University of Illinois at UrbanaChampaign, Illinois, USA.

Coil, J., and P. V. Kirch. 2005. An Ipomoean landscape: archaeology and the sweet potato in Kahikinui, Maui, Hawaiian Islands. Pages 71-84 in C. Ballard, P. Brown, R. M. Bourke, and T. Harwood, editors. The sweet potato in Oceania: a reappraisal. University of Sydney, Sydney, Australia.

Cordy, R. 2000. Exalted sits the chief: the ancient history of Hawai $i$ Island. Mutual Publishing, Honolulu, Hawai i, USA.

Diaz, H. F., E. R. Wahl, E. Zorita, T. W. Giambelluca, and J. K. Eischeid. 2016. A five-century reconstruction of Hawaiian Islands winter rainfall. Journal of Climate 29(15):5661-5674. http://dx.doi.org/10.1175/JCLI-D-15-0815.1

DiNapoli, R. J., and A. E. Morrison. 2017. A spatiotemporal model of risk and uncertainty for Hawaiian dryland agriculture and its implications for ahupua'a community formation. Journal of Archaeological Science: Reports 15:109-119. http://dx.doi. org/10.1016/j.jasrep.2017.07.001

Dye, T. S. 2011a. The tempo of change in the leeward Kohala field system, Hawai'i Island. Rapa Nui Journal 25(2):21-30.

Dye, T. S. 2011b. A model-based age estimate for Polynesian colonization of Hawaii. Archaeology in Oceania 46(3):130-138. http://dx.doi.org/10.1002/j.1834-4453.2011.tb00107.x

Dye, T. S. 2014. Wealth in old Hawai'i: good-year economics and the rise of pristine states. Archaeology in Oceania 49(2):59-85. http://dx.doi.org/10.1002/arco.5034

Erickson, C. L. 2006. Intensification, political economy, and the farming community; in defense of a bottom-up perspective of the past. Pages 233-265 in J. Marcus and C. Stanish, editors. Agricultural strategies. Cotsen Institute, Los Angeles, California, USA. 
Feng, X., A. Porporato, and I. Rodriguez-Iturbe. 2013. Changes in rainfall seasonality in the tropics. Nature Climate Change 3 (9):811-815. http://dx.doi.org/10.1038/nclimate1907

Field, J. S., T. N. Ladefoged, and P. V. Kirch. 2011a. Household expansion linked to agricultural intensification during emergence of Hawaiian archaic states. Proceedings of the National Academy of Sciences 108(18):7327-7332. http://dx.doi.org/10.1073/ pnas. 1103805108

Field, J. S., T. N. Ladefoged, W. D. Sharp, and P. V. Kirch. $2011 b$. Residential chronology, household subsistence, and the emergence of socioeconomic territories in Leeward Kohala, Hawai'i Island. Radiocarbon 53(4):605-627. http://dx.doi. org/10.1017/S0033822200039084

Frazier, A. G., and T. W. Giambelluca. 2017. Spatial trend analysis of Hawaiian rainfall from 1920 to 2012. International Journal of Climatology 37(5):2522-2531. http://dx.doi.org/10.1002/joc.4862

Giambelluca, T. W., Q. Chen, A. G. Frazier, J. P. Price, Y.-L. Chen, P.-S. Chu, J. K. Eischeid, and D. M. Delparte. 2013. Online rainfall atlas of Hawai'i. Bulletin of the American Meteorological Society 94(3):313-316. http://dx.doi.org/10.1175/BAMS-D-11-00228.1

Giambelluca, T. W., M. A. Nullet, T. A. Schroeder. 1986. Rainfall atlas of Hawaii. State of Hawaii Department of Land and Natural Resources Report R76, Honolulu, Hawaii, USA.

Giambelluca, T. W., X. Shuai, M. L. Barnes, R. J. Alliss, R. J. Longman, T. Miura, Q. Chen, A. G. Frazier, R. G. Mudd, L. Cuo, and A. D. Businger. 2014. Evapotranspiration of Hawaii. Final report submitted to the U.S. Army Corps of Engineers-Honolulu District, and the Commission on Water Resource Management, State of Hawai i, USA.

Gonschor, L., and K. Beamer. 2014. Toward an inventory of ahupua'a in the Hawaiian Kingdom: a survey of nineteenth- and early twentieth-century cartographic and archival records of the Island of Hawai' i. Hawaiian Journal of History 48:53-87.

Graf, A., W. Kuttler, and J. Werner. 2008. Mulching as a means of exploiting dew for arid agriculture? Atmospheric Research 87 (3-4):369-376. http://dx.doi.org/10.1016/j.atmosres.2007.11.016

Hahn, S. K. 1977. Sweet potato. Pages 237-248 in P. de T. Alvim and T. T. Kozlowski, editors. Ecophysiology of tropical crops. Academic, New York, New York, USA. http://dx.doi. org/10.1016/B978-0-12-055650-2.50013-7

Handy, E. S. C. 1940. The Hawaiian planter, volume I: his plants, methods, and areas of cultivation. Bishop Museum Press, Honolulu, Hawai 'i, USA.

Handy, E. S. C., E. G. Handy, and M. K. Pukui. 1972. Native planters in old Hawaii, their life, lore, and environment. Bishop Museum Press, Honolulu, Hawai i, USA.

Hommon, R. J. 2013. The ancient Hawaiian state: origins of a political society. Oxford University Press, Oxford, UK. http://dx. doi.org/10.1093/acprof:oso/9780199916122.001.0001

Kagawa, A. K., and P. M. Vitousek. 2012. The ahupua'a of Puanui: a resource for understanding Hawaiian rain-fed agriculture. Pacific Science 66(2):161-172. http://dx.doi. org/10.2984/66.2.6
Kamakau, S. M. 1976. Na hana a ka po'e kahiko. Bishop Museum Press, Honolulu, Hawai'i, USA.

Kelly, M. 1983. Na mala o Kona. Bishop Museum Press, Honolulu, Hawaii, USA.

Kirch, P. V. 1984. The evolution of the Polynesian chiefdoms. Cambridge University Press, Cambridge, UK.

Kirch, P. V. 1994. The wet and the dry: irrigation and agricultural intensification in Polynesia. University of Chicago Press, Chicago, Illinois, USA.

Kirch, P. V. 2010. How chiefs became kings: divine kingship and the rise of archaic states in ancient Hawai $i$. University of California Press, Berkeley, California, USA. http://dx.doi. org/10.1525/california/9780520267251.001.0001

Kirch, P. V. 2014. Kua'aina kahiko: life and land in ancient Kahikinui, Maui. University of Hawai'i Press, Honolulu, Hawai'i, USA. http://dx.doi.org/10.21313/hawaii/9780824839550.001.0001

Kurashima, N., J. Jeremiah, and T. Ticktin. 2017. I ka wâ ma mua: The value of a historical ecology approach to ecological restoration in Hawaili. Pacific Science 71(4):437-456. http://dx. doi.org/10.2984/71.4.4

Ladefoged, T. N., and M. W. Graves. 2000. Evolutionary theory and the historical development of dry-land agriculture in North Kohala, Hawai'i. American Antiquity 65(3):423-448. http://dx. doi.org/10.2307/2694529

Ladefoged, T. N., and M. W. Graves. 2008. Variable development of dryland agriculture in Hawai i: a fine-grained chronology from the Kohala Field System, Hawai'i Island. Current Anthropology 49(5):771-802. http://dx.doi.org/10.1086/591424

Ladefoged, T. N., M. W. Graves, and R. P. Jennings. 1996. Dryland agricultural expansion and intensification in Kohala, Hawai $i$ island. Antiquity 70(270):861-880. http://dx.doi.org/10.1017/ $\underline{\mathrm{S} 0003598 \mathrm{X} 0008412 \mathrm{X}}$

Ladefoged, T. N., M. W. Graves, and M. D. McCoy. 2003. Archaeological evidence for agricultural development in Kohala, Island of Hawai'i. Journal of Archaeological Science 30 (7):923-940. http://dx.doi.org/10.1016/S0305-4403(02)00271-6

Ladefoged, T. N., P. V. Kirch, S. M. Gon III, O. A. Chadwick, A. S. Hartshorn, and P. M. Vitousek. 2009. Opportunities and constraints for intensive agriculture in the Hawaiian archipelago prior to European contact. Journal of Archaeological Science 36 (10):2374-2383. http://dx.doi.org/10.1016/j.jas.2009.06.030

Ladefoged, T. N., C. T. Lee, and M. W. Graves. 2008. Modeling life expectancy and surplus production of dynamic pre-contact territories in leeward Kohala, Hawai'i. Journal of Anthropological Archaeology 27(1):93-110. http://dx.doi.org/10.1016/j.jaa.2007.11.001

Ladefoged, T. N., M. D. McCoy, G. P. Asner, P. V. Kirch, C. O. Puleston, O. A. Chadwick, and P. M. Vitousek. 2011. Agricultural potential and actualized development in Hawai i: an airborne LiDAR survey of the leeward Kohala field system (Hawai' $\mathrm{i}$ Island). Journal of Archaeological Science 38(12):3605-3619. http://dx.doi.org/10.1016/j.jas.2011.08.031

Lee, C. T., S. Tuljapurkar, and P. M. Vitousek. 2006. Risky business: temporal and spatial variation in preindustrial dryland 
agriculture. Human Ecology 34(6):739-763. http://dx.doi. org/10.1007/s10745-006-9037-x

Lincoln, N., O. Chadwick, and P. Vitousek. 2014. Indicators of soil fertility and opportunities for precontact agriculture in Kona, Hawai'i. Ecosphere 5(4):1-20. http://dx.doi.org/10.1890/ES13-00328.1

Lincoln, N. K., A. Kagawa-Viviani, K. Marshall, and P. Vitousek. 2017. Observations of sugarcane in traditional Hawaiian cropping systems. Pages 273-282 in R. Murphy, editor. Sugarcane: production systems, uses, and economic impact. Nova Science Publishers, Hauppauge, New York, USA.

Lincoln, N., and T. Ladefoged. 2014. Agroecology of pre-contact Hawaiian dryland farming: the spatial extent, yield and social impact of Hawaiian breadfruit groves in Kona, Hawai i. Journal of Archaeological Science 49(Supplement C):192-202. http://dx. doi.org/10.1016/j.jas.2014.05.008

Lincoln, N. K. and P. Vitousek. 2016. Nitrogen fixation during decomposition of sugarcane (Saccharum officinarum) is an important contribution to nutrient supply in traditional dryland agricultural systems of Hawai'i. International Journal of Agricultural Sustainability 14(2):214-230. http://dx.doi. org/10.1080/14735903.2015.1071547

Lincoln, N. K., and P. M. Vitousek. 2017. Indigenous Polynesian agriculture in Hawai'i. Oxford Research Encyclopedias; Environmental Science March (2017). http://dx.doi.org/10.1093/ acrefore/9780199389414.013.376

Malo, D. 1951. Hawaiian antiquities: moolelo Hawaii. Second edition. Bishop Museum Press, Honolulu, Hawai i, USA.

Marshall, K., C. Koseff, A. Roberts, A. Lindsey, A. KagawaViviani, N. K. Lincoln, and P. Vitousek. 2017. Restoring people and productivity to Puanui: challenges and opportunities in the restoration of an intensive rain-fed Hawaiian field system. Ecology and Society 22(2):23. http://dx.doi.org/10.5751/ ES-09170-220223

McCoy, M. 2014. The significance of religious ritual in ancient Hawai'i. Journal of Pacific Archaeology 5(2):72-80.

McCoy, M. D., T. N. Ladefoged, M. W. Graves, and J. W. Stephen. 2011. Strategies for constructing religious authority in ancient Hawai'i. Antiquity 85(329):927-941. http://dx.doi.org/10.1017/ $\underline{\mathrm{S} 0003598 \mathrm{X} 0006840 \mathrm{X}}$

McCoy, M. D., M. A. Mulrooney, M. Horrocks, H. Cheng, and T. N. Ladefoged. 2017. Evaluating agricultural bet-hedging strategies in the Kona Field System: new high precision ${ }^{230 \mathrm{Th} / \mathrm{U}}$ and ${ }^{14} \mathrm{C}$ dates and plant microfossil data from Kealakekua, Hawai' i Island. Archaeology in Oceania 52(1):70-80. http://dx.doi. org/10.1002/arco.5121

McIvor, I. H., and T. N. Ladefoged. 2018. Intermittent irrigation in the Waimea Field System, Hawai'i Island: a computational fluid dynamics model. Journal of Archaeological Science: Reports 17:335-345. http://dx.doi.org/10.1016/j.jasrep.2017.09.021

Monteith, J. L. 1973. Principles of environmental physics. Elsevier, New York, New York, USA. http://dx.doi.org/10.1063/1.3128494

Office of Hawaiian Affairs. 2009. Ahupuaa. Polygon shapefile, Hawaii Statewide GIS Program. State of Hawaii, Office of
Planning, Honolulu, Hawaii, USA. [online] URL: http://files. hawaii.gov/dbedt/op/gis/data/ahupuaa.shp.zip

Phillips, N., T. N. Ladefoged, B. W. McPhee, and G. P. Asner. 2015. Location, location, location: a viewshed analysis of heiau spatial and temporal relationships in leeward Kohala, Hawai'i. Journal of Pacific Archaeology 6(2):21-40.

Pukui, M. K. 1983. 'Ôlelo no'eau: Hawaiian proverbs \& poetical sayings. Bishop Museum Press, Honolulu, Hawaii, USA.

Rosendahl, P. H. 1972. Aboriginal agriculture and residence patterns in upland Lapakahi, island of Hawaii. Dissertation. University of Hawaii at Manoa, Honolulu, Hawaii, USA.

Schilt, R. 1984. Subsistence and conflict in Kona, Hawai $i$ : an archaeological study of the Kuakini Highway Realignment Corridor. Departmental Report Series 84-1, Department of Anthropology, Bishop Museum, Honolulu, Hawaii, USA.

Setiyono, T., K. G. Cassman, A. K. Kagawa, and P. M. Vitousek. 2011. Before globalization - pre-contact intensive agriculture and society in Kohala, Hawai'i: modeling of growth and yield of sweet potato and taro. Report on NSF award \#0709668. Department of Agronomy and Horticulture, University of Nebraska, Lincoln, Nebraska, USA.

Solis, R. K. 1999. Kekahi mau pule mahi ai. University of Hawai' i at Mânoa, Honolulu, Hawai'i, USA.

State of Hawaii Office of Planning. 2003. Hillshade images. TIF, Hawaii Statewide GIS Program. State of Hawaii, Office of Planning, Honolulu, Hawaii, USA. [online] URL: http://files. hawaii.gov/dbedt/op/gis/data/hillhaw.tif.zip

Stock, J., J. Coil, and P. V. Kirch. 2003. Paleohydrology of arid southeastern Maui, Hawaiian Islands, and its implications for prehistoric human settlement. Quaternary Research 59(1):12-24. http://dx.doi.org/10.1016/S0033-5894(02)00015-7

Tomonari-Tuggle, M. J. 2006. Archeological data recovery investigations for the northern portion of Captain Cook Ranch. International Archeological Research Institute Inc., Honolulu, Hawai i, USA.

Trapp, K. 2003. No ka mahi'ai 'ana, mâhele 3. Ka Ho'oilina: Puke Pai 'Ôlelo Hawai i 2:2-15.

Tsuha, A. K. 2007. Kaulana mahina: He 'ônaehana 'alemanaka Hawai $i$. Thesis. University of Hawai'i at Manoa, Honolulu, Hawai'i, USA.

Valenzuela, H., S. Fukuda, and A. Arakaki. 1994. Sweetpotato production guides for Hawai $i$. Hawai'i Institute of Tropical Agriculture and Human Resources, Honolulu, Hawai'i, USA. [online] URL: https://www.ctahr.hawaii.edu/oc/freepubs/pdf/ RES-146.pdf

Vitousek, P. M., and O. A. Chadwick. 2013. Pedogenic thresholds and soil process domains in basalt-derived soils. Ecosystems 16 (8):1379-1395. http://dx.doi.org/10.1007/s10021-013-9690-z

Vitousek, P. M., O. A. Chadwick, S. C. Hotchkiss, T. N. Ladefoged, and C. M. Stevenson. 2014. Farming the rock: a biogeochemical perspective on intensive agriculture in Polynesia. Journal of Pacific Archaeology 5(2):51-61. 
Vitousek, P. M., T. N. Ladefoged, P. V. Kirch, A. S. Hartshorn, M. W. Graves, S. C. Hotchkiss, S. Tuljapurkar, and O. A. Chadwick. 2004. Soils, agriculture, and society in precontact Hawai' i. Science 304(5677):1665-1669. http://dx.doi.org/10.1126/ $\underline{\text { science. } 1099619}$

Wilson, L. A. 1977. Root crops. Pages 187-236 in P. de T. Alvim and T. T. Kozlowski, editors. Ecophysiology of tropical crops. Academic, New York, New York, USA. http://dx.doi. org/10.1016/B978-0-12-055650-2.50012-5

Yen, D. E. 1974. The sweet potato and Oceania: an essay in ethnobotany. Bishop Museum Press, Honolulu, Hawai'i, USA. 
Appendix 1. Descriptions and sources of spatial data utilized for analyses and maps. For R scripts used for this analysis, see https://github.com/akkagawa/DrylandAg.

\begin{tabular}{|c|c|c|c|}
\hline Dataset & \multicolumn{2}{|c|}{ Description } & Source \\
\hline Dryland field systems & \multicolumn{2}{|c|}{ polygon } & Ladefoged et al. (2009) \\
\hline Ahupua'a boundaries & \multicolumn{2}{|c|}{ polygon } & Office of Hawaiian Affairs (2009) \\
\hline Elevation (m) & \multicolumn{2}{|c|}{$10 \mathrm{~m} \mathrm{DEM}$} & U.S. Geological Survey (2015) \\
\hline Climate datasets (250 m) & $\begin{array}{l}\text { Mean } \\
\text { annual }\end{array}$ & $\begin{array}{l}\text { Mean } \\
\text { monthly }\end{array}$ & Source \\
\hline Rainfall (P, mm) & $\mathrm{x}$ & $\mathrm{X}$ & Giambelluca et al. (2013) \\
\hline Cloud frequency (ratio) & $\mathrm{x}$ & $\mathrm{x}$ & Giambelluca et al. (2014) \\
\hline Shortwave solar radiation $\left(\mathrm{Wm}^{-2}\right)$ & $\mathrm{x}$ & $\mathrm{x}$ & \\
\hline Diffuse solar radiation $\left(\mathrm{Wm}^{-2}\right)$ & $\mathrm{x}$ & $\mathrm{X}$ & \\
\hline $\mathrm{T}_{\max }\left({ }^{\circ} \mathrm{C}\right)$ & $\mathrm{x}$ & $\mathrm{x}$ & \\
\hline $\mathrm{T}_{\min }\left({ }^{\circ} \mathrm{C}\right)$ & $\mathrm{x}$ & $\mathrm{x}$ & \\
\hline $\mathrm{T}_{\text {mean }}\left({ }^{\circ} \mathrm{C}\right)$ & $\mathrm{x}$ & $\mathrm{x}$ & \\
\hline Relative humidity (\%) & $\mathrm{x}$ & $\mathrm{x}$ & \\
\hline Vapor pressure deficit $(\mathrm{Pa})$ & $\mathrm{x}$ & $\mathrm{x}$ & \\
\hline Wind speed $\left(\mathrm{ms}^{-1}\right)$ & $\mathrm{x}$ & $\mathrm{n} / \mathrm{a}$ & \\
\hline $\begin{array}{l}\text { Penman Monteith potential } \\
\text { evapotranspiration (PET, mm) }\end{array}$ & $\mathrm{x}$ & $\mathrm{x}$ & \\
\hline Actual evapotranspiration (mm) & $\mathrm{x}$ & $\mathrm{x}$ & \\
\hline Aridity & $\mathrm{x}$ & $\mathrm{x}$ & $\begin{array}{l}\text { Derived as PET/P from Giambelluca } \\
\text { et al. (2013, 2014) }\end{array}$ \\
\hline Rainfall seasonality metrics & $\mathrm{n} / \mathrm{a}$ & $\mathrm{x}$ & $\begin{array}{l}\text { Derived from Giambelluca et al. } \\
\text { (2013) based on methods of Feng et } \\
\text { al. (2013) }\end{array}$ \\
\hline
\end{tabular}


Appendix 2. Cultivable area as a function of various minimum monthly temperature and moisture criteria for rainfall (Figure A2.1) or aridity (Figure A2.2).

Figure A2.1 Fraction of field system that meets thresholds for monthly air temperature and monthly rainfall for at least one month of the year: Kohala (top), Kona (middle), and Ka' $\bar{u}$ (bottom). Monthly air temperature criterion (minimum) indicated on the y-axis and monthly rainfall criterion (minimum) indicated on the $\mathrm{x}$-axis. Marker at rainfall $=90 \mathrm{~mm}$ and temperature $=18{ }^{\circ} \mathrm{C}$ indicates the fixed thresholds used for visualizing seasonal cultivation envelopes.

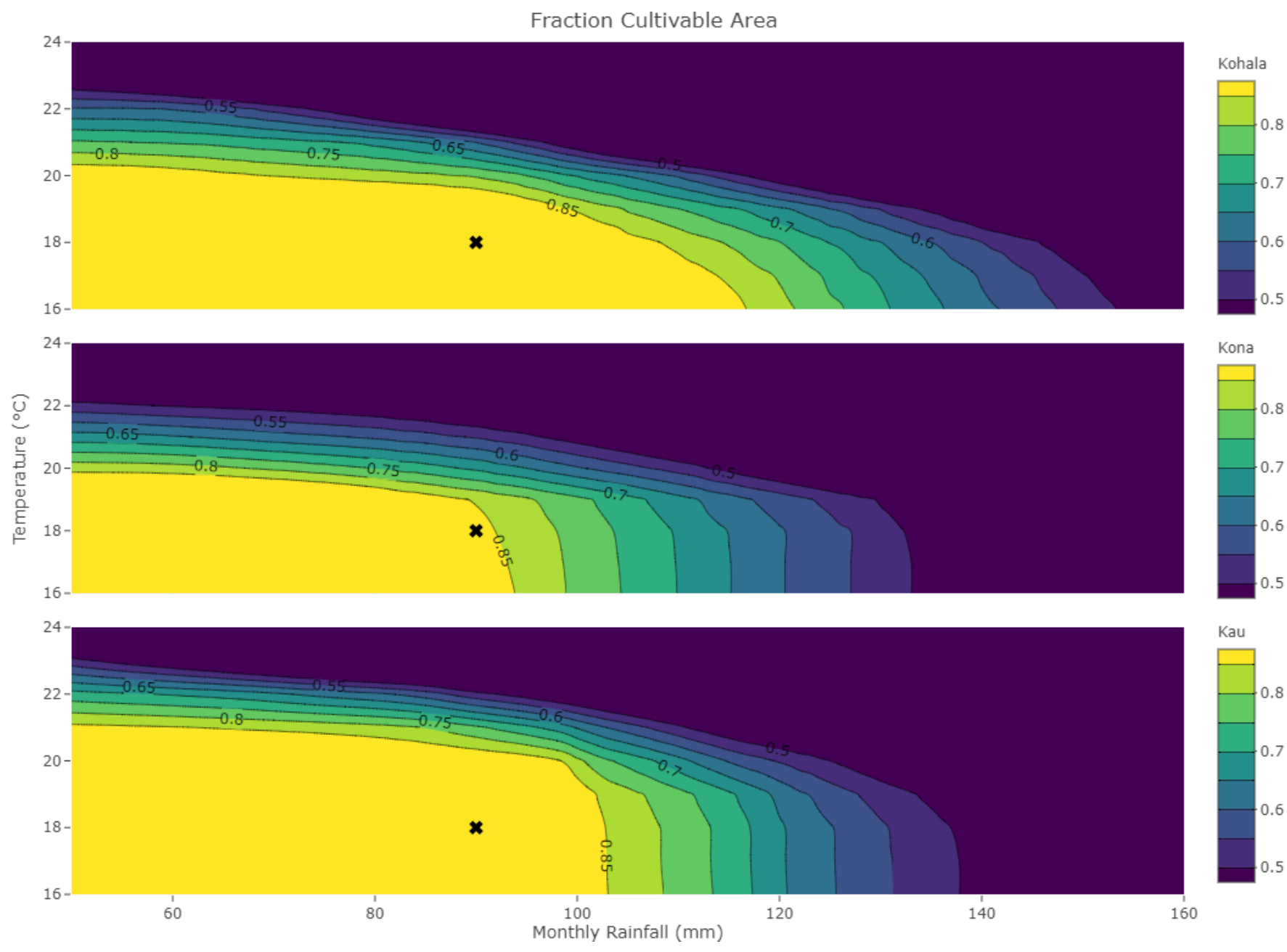


Figure A2.2 Fraction of field system that meets thresholds for monthly air temperature and monthly aridity for at least one month of the year: Kohala (top), Kona (middle), and Ka' $\bar{u}$ (bottom). Monthly air temperature criterion (minimum) indicated on the y-axis and monthly aridity criterion (maximum) indicated on the $\mathrm{x}$-axis. Marker at aridity $=2.5$ and temperature $=18$ ${ }^{\circ} \mathrm{C}$ indicates the fixed thresholds used for visualizing seasonal cultivation envelopes.

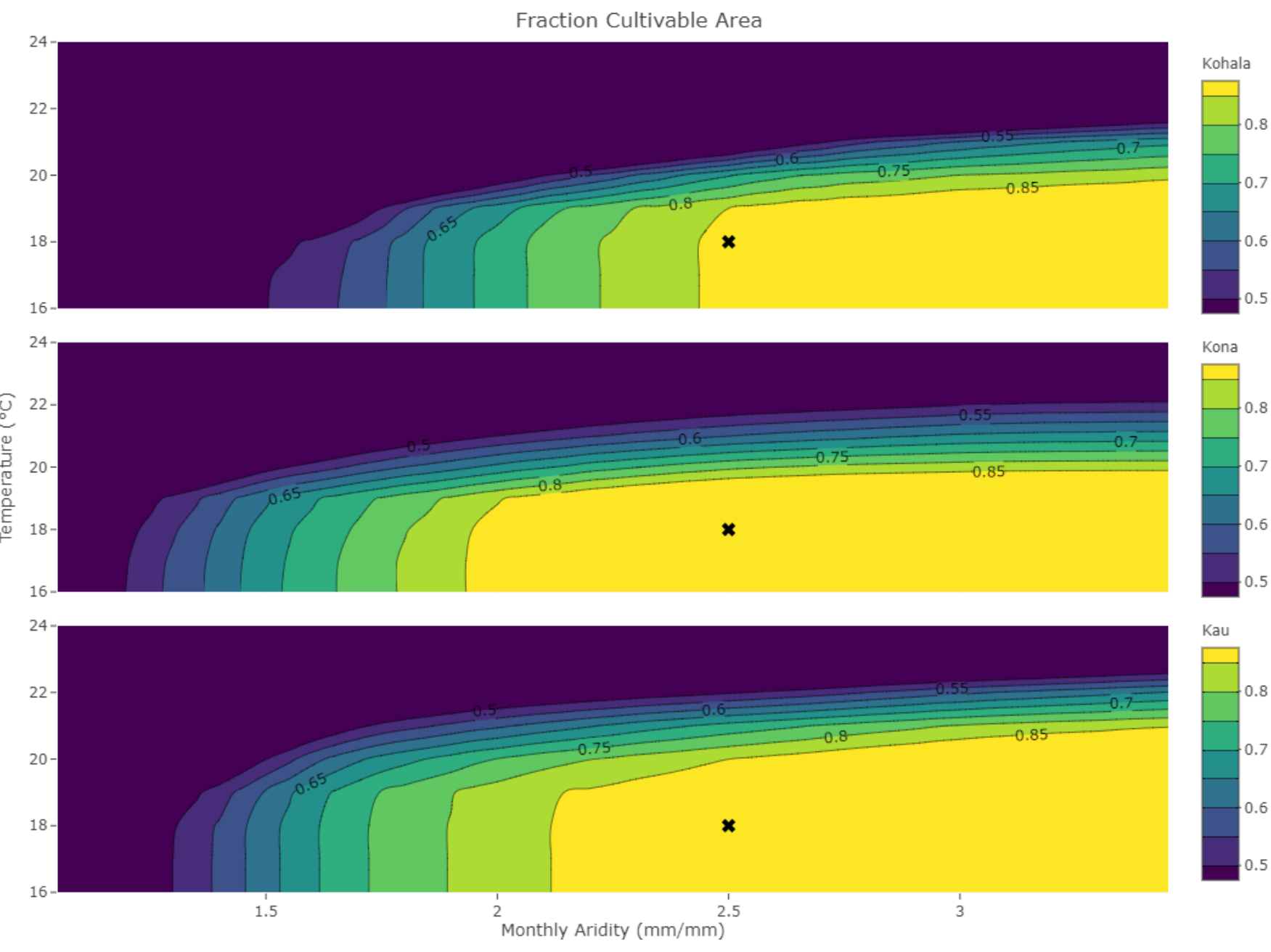


Appendix 3. For Kohala, Kona, and Ka'ū field systems, mean annual cycle for minimum and maximum air temperatures (a-c), relative humidity (d-f), and vapor pressure deficit (g-i).

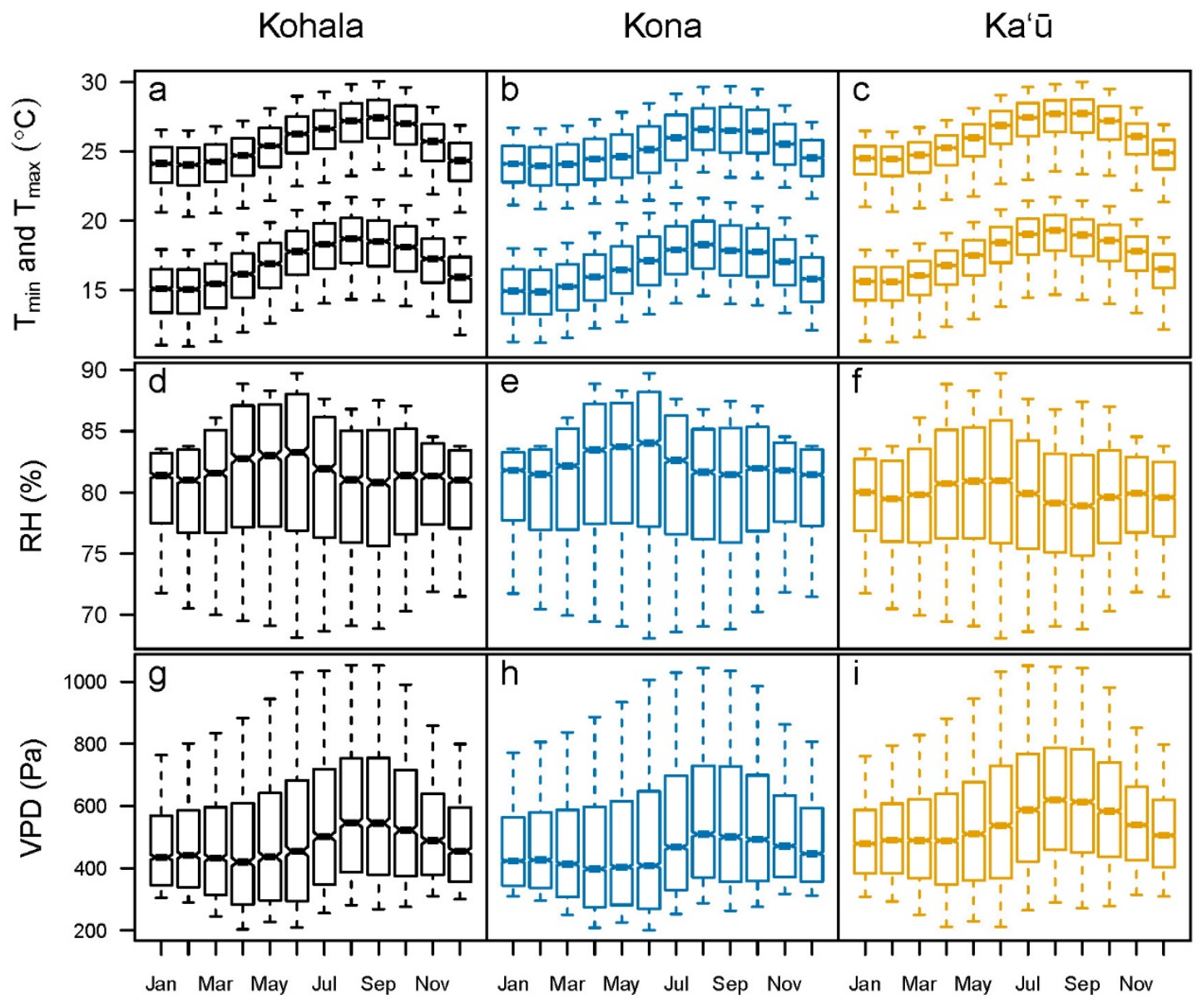

